\author{
Oleinikova G. O., \\ Ph.D. in Philology, Associate Professor, \\ Head of the Department of English Philology \\ Izmail State University of Humanities
}

\title{
TIME - AN INTEGRAL FEATURE OF THE VECTOR MOVEMENT OF SCIENCE-FICTION NARRATIVE
}

\begin{abstract}
Summary. Any literary text contains semantic categories that are universal for it. In this article special interest is given to the universal category of time in the text of the science fiction genre. In recent decades, in the field of various sciences, there has been an increased interest in the forms of implementation of a number of fundamental laws of the structure of matter. These fundamental laws include the forms of space and time. The specific properties of time are its duration/fluidity, onedimensionality and irreversibility. Time as a condition of being has a universal character, it is one of the main ontological and linguistic categories that usually form the conceptual basis of the world and without which no language system can be conceived. Therefore, time throughout the history of mankind has been an object of study of a wide variety of sciences: from natural and exact (physics, mathematics, biology, geology) to humanitarian, primarily in text linguistics. Today, it is customary to consider time as the fourth dimension (in relation to our space) which is very relevant for the science fiction genre. This means that any object, even if it is motionless in the space we are accustomed to, still continues its movement along the fourth axis - time. The direction of this movement is vector, that is, the object moves from its location to its specific target, and, as it is commonly believed, evenly in leaps forward or backward. The aim of the article is to study the representation of temporal organization in works of science fiction discourse. In this study, the hypothesis of a temporal shift in works of the sci-fi genre is the starting point, the dominant principle of which is the structuring of the counterfactual or fictional world, the displacement of the center of the coordinate vector grid along the axis of space and along the axis of time. By temporal shift, we mean two different, although often inextricably linked phenomena. One of them concerns the vector shift of the narrative perspective, the second one concerns the arbitrary movement in time.
\end{abstract}

Key words: time, hypothesis, temporal shift, narrative perspective, movement in time.

The problem of the article. A category of time is considered as the most important category of human being, consciousness, language and culture, as one of the basic component of the language picture of the world. Time as the main condition of being has a universal character. It is one of the main ontological and linguistic categories which usually forms the conceptual basis of the world and without which not a single linguistic system can be presented. Therefore, time throughout the history of mankind has been the object of studying a wide variety of sciences: from natural: physics, mathematics, biology and geology to arts: linguistics, languages, literature, religion and certainly philosophy.

One of the important trends that determined the surge of interest in the topic of Time and new approaches to its study in native linguistics of recent decades has become the general anthropological orientation of linguistic research. As the scientists mentioned, the basic scientific paradigm has changed: from "immanent" linguistics which was aimed at studying the language system to anthropological, in which language is considered as a constitutive property of a person. Anthropological linguistics bears the interdisciplinary nature of research. As it was mentioned by G. Oleinikova "Today scientists speak of interdisciplinary synthesis, which involves the allocation of the main created sets and opened achievements which have been already existed to the priorities of contemporary humanities" [5, p. 233].

The idea of anthropocentricity of language is not new in itself: even V. Humboldt considered language as a unified spiritual energy of the people and formulated the idea of the existence of a special, linguistic worldview as a scientific and philosophical problem.

At the end of the XX and the beginning of the XXI century, studies of the linguistic picture of the world were carried out in the framework of the theory of linguistic relativity (L. Weisgerber, E. Sapir, etc.): language creates a picture of the world and "imposes" its cultural and national outlook on its carriers. Thus, the picture of the world is the basic concept of anthropological linguistics, and the philosophical-cultural direction becomes leading in Linguistics.

Studying Anthropological Linguistics from the perspective of interdisciplinarity, we see that this approach is formed at the intersection of such sciences as Linguistics, Ethnography, Cultural studies and Aesthetics, which is more promising in modern philological studies of languages. The purpose of which is to study the language in a close connection with human consciousness, thinking, spiritual and practical activities [1] with the leading methodological principle of anthropotsinstrism, "the study of language, according to which man is regarded as the center and the highest goal of the universe" [6, p. 31].

Accordingly, Time becomes more and more often the subject of the analyses in the works of linguists. It is investigated not as a grammatical category, but as the life time of a person, nation, ethnos, which is reflected and expressed in language.

At the various stages of the society development, in different layers of the same society and even a separate individuality, the objective existing of Time is subjectively perceived and realized by people in different civilizations, this category is perceived and applied differently. History shows us the examples where each era contributed to the content of this language category of Time (therefore, we speak about the time of primitive society, the Middle Ages, the Renaissance), and each historical type of culture was characterized by its interpretation of time. Of course, every culture, era is characterized by a variety of models of Time perception, but 
at the same time they give a single type of perception inherent in this culture. All of the above indicates that the problem of Time needs a comprehensive study for to solve it and the results of both the natural sciences and the humanities must be assimilated.

Different linguists considered and offered different models of Time. So, V. Muryanov wrote about the circular model of the movement of Time, G. Gachev - about the model of rolling, "oscillation", G. Wrigt spoke about Time as a changing and spreading flow, Yu. N. Karaulov writes about historical (diachronic, linguistic) and actual (syntagmatic, speech) Time, accordingly, builds a separate linguistic model of the folklore world - a model of the thesaurus description of the folk poetry language, which also includes Time [3].

The aim of this article is to demonstrate the artistic time model in the texts of the science fiction genre, where Time can be perceived both in reality and in its unrealistic refraction.

The chronotope (time and space) of a literary work is the most important characteristic of its genre attribution. For science fiction works, this thesis turns out to be extremely relevant, as it is this genre that presupposes the obligatory depiction of other world, surreal, counterfactual, quasireal reality. In this study, the starting point is the temporal shift hypothesis, the dominant principle of which is the structuring of a counterfactual or fictional world, the shift of the center of the coordinate grid along the Space axis and the Time axis. By temporal shift, we mean two different, although often inextricably linked phenomena. One of them concerns the shift of narrative perspective, the second concerns arbitrary movement in time. In this article we are going to speak about the shift of time or the shift of narrative perspective in the science fiction artistic texts.

A shift in a narrative perspective is a shift in the time of narration into the future, in which the reader is made aware by some compositional and speech methods that the narration of events is conducted not in the historical period of time in which the work is created and in which the reader lives, but in more or less distant future.

A writer living in real-time coordinates creates a work in which fictional events are presented as occurring, i.e. events are in the past in relation to the time of telling about them, and the story is conducted from the point of view of the narrator, living in a more or less distant future with respect to the time of writing the work. The temporal localization of the fabulous past (i. e. the time of the events are described) is in different ways related to the real present (i. e. the period of writing and reading a literary work).

The fabulous past can fit into the plan of the real future, or it can coincide with the plan of the real past. In other words, a storyteller from the future can tell about a time that has not yet arrived for the author/reader (fabulous past $=$ real future) or a storyteller from the future can talk about events supposedly taking place long before the time of writing (fabulous past $=$ real past $)$.

Speaking about the real present/past, we mean both the time of creation of a science fiction work and the time of its reading.

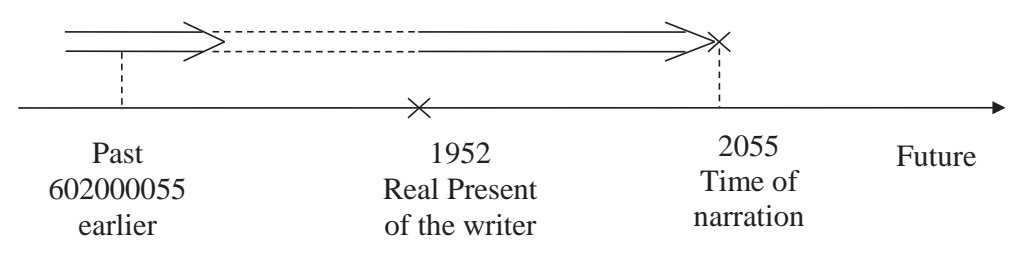

Fig. 1. Temporal shift of narrative perspective in the story R. Brad "A Sound of Thunder"
Naturally, the second indicator is always different from the first: they read the work years later, sometimes decades after its publication. In some, not frequent cases, the time distance between readers and the author plays a role in the functioning of a science fiction work, it means how readers perceive the plot of the unreal story in later years.

However, this distance is relevant for works with a slight shift in narrative perspective. For example, Robert Heinlein's novel "The Door into Summer" was published in 1956 [11]. The narrative perspective in it is shifted only 25 years into the future: the plot of futuristic events dates back to 1970 , then the narrator moves 30 years ahead and the development of events takes place in 2000. Both of these temporary plans were a plot future for the author and reader of 1950-1960. For today's reader, the events described are projected onto not very distant past. In this regard, there is additional reader interest in assessing the predictive abilities of Robert Heinlein.

However, it should be emphasized that in the vast majority of cases, the shift in the narrative perspective is carried out on such a large scale that the distance between the time of writing the work and the time of its later reading is completely leveled. For example, the narration in A. Azimov's novel "Foundation" is temporally localized in the thirteenth millennium, however, it tells about the events of the distant plot history - the eleventh millennium. The distance between the real present (the novel is written and read in the second and the beginning of the third millennium) and the storyline of the events described (the eleventh millennium) is 9 millennia. It is self-evident that, at such scales of temporal shifts, the time of plot events and the story about them are equally transcendentally futural for both the writer and his subsequent readers.

The distance of narrative time can take on galactic proportions. For example, in A. Azimov's story "Take a Match" [8], by the time of the plot events, the Earth has long ceased to be an inhabited planet, the only place for the human race, and has turned into an ordinary historical museum: There were smoggy areas in the galaxy, as once there were on Earth, when it was the sole home of humanity, rather than the carefully preserved museum-piece it now was.

Obviously, such a transcendental removal of the narrative perspective is already devoid of any chronological specificity. It is just a "very distant/far future".

A shift in narrative perspective is a powerful means of alienation the depicted unreal world. Shifting the time of storytelling into the future, the author of a science fiction work takes a carte blanche to depict a counterfactual reality, which in this case can be not only futuristic, but also prehistoric. So, the narrative plan of R. Bradbury's short story "A Sound of Thunder" [9] is not very far removed into the future - by 100 years (in 2055), and from there the character falls into the deepest past - 60 million years ago, in dinosaur era. The fabulous past of the story is uniquely localized within the distant past from the point of view of the writer and his current and subsequent readers. However, the localization of the plotnarrative future is less clear: already in the notso-distant 2055. Reading about the hero's journey into the dinosaur era, the reader will appreciate the author's imagination in creating a counterfactual world of the past, but at the same time he will have the opportunity to assess the philosophical and political forecast of R. Bradbury, who predicted the threat of totalitarianism in the United States in the 21 st century. 
As we can see, the plot of this story is clearly localized within the distant past from the point of view of the writer and his current and subsequent readers. However, the localization of the plotnarrative future is less clear: not far from 2055. Reading about the hero's journey into the dinosaur era, the reader will appreciate the author's imagination in creating a counterfactual world of the past, but at the same time he will have the opportunity to assess the philosophical and political forecast of R. Bradbury, who predicted the threat of totalitarianism in the United States in the XXI century.

A shift in the narrative perspective into the future can be implied by references to a pseudo-historical past that supposedly unites the narrator and the reader. For example, the narrator from the "Jupiter Five" A. Clark (1957) says: Perhaps you can still remember the astonishment when the first Martian expedition found the remains of not of one ancient civilization, but of two [10, p. 42].

Even more than half a century after the story was published on an expedition to Mars, the contact with Martian civilizations is a futuristic phenomenon, their reference to events that had taken place long ago and already forgotten presumably puts the narrative perspective a considerable distance forward along the Time axis.

The paradox, however, is that the time of the events described is shifted into the future by no means so far. It is only 2040 year. But the psychology of perceiving the future is such that the reader easily interprets any futuristically localized narrative as surreal. The magic of another millennium works and the 21st century is thought of as a different era. In the development of the plot, one of the characters was caught stealing; he is locked in the cabin of a spaceship. Trying to resist, he exclaims: "Please don 't be so melodramatic", he said haughtily. "This is twenty-first century, not the Wild West back in 1800 " [10, p. 44].

In this case, the author refers the reader to the real historical events of the era of the conquest of the Wild West. Thus, he appeals to a common past (for readers and characters) which can be both fictitious and true. The removal of one and the other appealing makes the story fascinating and compelling.

The futurity of the starting point of the story gives the science fiction writer unlimited freedom of fiction when designing the depicted world. The exact figures for such a narrative shift are not very important: they can be millions or hundreds of thousands of years. The fact of distance of narration is important.

Conclusions. In the conclusion we want to say that the exact figures for such a narrative shift are not very important: they can be millions or hundreds of thousands of years. The fact namely of the distance of narration is important in science fiction genre. A narrative perspective of a science fiction text is always presented through a shift in the time of narration into the future, in which the reader is made aware by some compositional and speech methods that the narration of events is not in the historical period of time when the work is created and in which the reader lives, but in more or less distant future. The events described in science fiction literature often not only never happened, but, most importantly, are impossible based on today's scientific picture of the world. In the future, in our opinion, it will be interesting and necessary to study the figure of the narrator of a science fiction work, with the goal of a more detailed analysis of the movement of the characters of the analyzed genre in a fictional temporal plane of the narrative.

\section{References:}

1. Жеребило Т.В. Языковое состояние в условиях билингвизма (на примере Чеченской Республики). Назрань : Кеп, 2016. 198 с.

2. Булатецька Л.І. Теорія і теоретизація у лінгвістиці. Вінниця : Нова книга, 2004. 176 с.

3. Караулов Ю.Н. Русский язык и языковая личность. Москва : Наука, 1987. 261 с.

4. Олейникова Г.А. Особенности организации повествовательной структуры научно-фантастических произведений. Іноземна філологія на межі тисячоліть / ред. І.С. Шевченко. Харків, 2000. C. 217-218.

5. Олейникова Г.А. Пространственно-временные координаты интродуктивных абзацев в научно-фантастической прозе. Актуальні дослідження іноземних мов і літератур : матеріали міжвузівської наукової конференції молодих учених. Донецьк, 2003. С. 233-236.

6. Селіванова О.О. Сучасна лінгвістика. Полтава : Довкілля, 2008. $711 \mathrm{c}$

7. Fludernik M. Towards a "Natural" Narratology. London : Routledge, 1996. 349 p.

8. Asimov I. Take a Match. Science Fiction: English and American Short Stories / by I. Asimov et al. Moscow : Progress Publishers, 1979. P. 23-40.

9. Bradbury R. A Sound of Thunder. Science Fiction: English and American Short Stories / by I. Asimov et al. Moscow : Progress Publishers, 1979. P. 68-80.

10. Clarke A. Jupiter Five. Science Fiction: English and American Short Stories / by I. Asimov et al. Moscow : Progress Publishers, 1979. P. 40-68.

11. Heinlein R. The Door into Summer. URL: https://booksonline.com.ua/ view.php?book=139323.

Олейнікова Г. О. Час - інтегральна риса векторного руху науково-фантастичного наративу

Анотація. Будь-який художній текст втілює універсальні для нього смислові категорії. У дослідженні особливий інтерес приділяється універсальній категорії часу в тексті науково-фантастичного жанру. В останні десятиліття в різних науках значна увага приділяється вивченню реалізації фундаментальних законів структури матерії. До таких фундаментальних законів належать форми простору й часу. Специфічними властивостями часу є його тривалість/ плинність, одномірність і незворотність. Час як умова буття має загальний характер, він є однією з головних онтологічних і мовних категорій, які зазвичай утворюють концептуальну основу світу, без нього не мислиться жодна мовна система. Тому час упродовж історії людства був об'єктом вивчення різних наук: від природних і точних (фізики, математики, біології, геологіï) до гуманітарних (насамперед лінгвістики тексту). У сучасному світі прийнято розглядати час як четвертий вимір (стосовно нашого простору), що дуже актуально для жанру наукової фантастики. Це означає, що будь-який об'єкт, навіть якщо він нерухомий у звичному нам просторі, усе одно продовжує свій рух у четвертому часовому векторі - тимчасовому. Напрямок цього руху - векторний, тобто предмет переміщається від свого місця розташування до певної мети рівномірно (таке можна спостерігати в багатьох художніх творах) або може рухатися стрибками вперед чи назад (що притаманно жанру наукової фантастики). Метою статті $\epsilon$ вивчення представленості темпоральної організації у творах науково-фантастичного дискурсу. У дослідженні вихідною $є$ гіпотеза темпорального зсуву у творах науковофантастичного жанру, домінуючим принципом якого $\epsilon$ структурування контрфактичних або вигаданих світів, зміщення центру координатної векторної сітки по осях простору й часу. Під темпоральним зрушенням ми розуміємо два різні, хоча нерідко нерозривно пов'язані, феномени. Один iз них стосується векторного зсуву наративної перспективи, другий - довільного переміщення в часі.

Ключові слова: час, гіпотеза, темпоральне зрушення, наративна перспектива, переміщення в часі. 